\title{
Occurrence of Sialic Acid in an Insect
}

\author{
昆虫にも存在したシアル酸 \\ Roth, J., Kempf, A., Reuter, G., Shauer, R., and Gehring, W.J. Science (1992) 256, 673-675
}

Key Words: N-CAM, Drosophila, , ganglia, polysialic acid, sialic acid

The derivatives of neuraminic acid are collectively called sialic acids. Sialic acids exist widely in nature, except in plants, mainly bound form in glycoproteins, glycolipids, and capsular polysaccharides of certain bacteria. All of the sialic acids found in nature are $N$-substituted with aminoacyl residues at C-5, such as $\mathrm{N}$-acetylneuraminic acid and $\mathrm{N}$ glycolyl neuraminic acid. Sialic acids exist in very various linkages in nature at the non-reducing end or side chain of the oligosaccharides or in the oligo/polysialic acid(PSA) residues. The screening effect of the recognition site or the antigenic determinant resulting from the anionic charge of the carboxyl group of sialic acid is well known. On the other hand, sialic acids are critical for the recognition site of the specific molecule or organ, such as interaction of viruses with their host cells or the life of serum glycoprotein. Recently, we have been very interested in the existence of sialic acids in the oncospecific antigens, ligands for endothelial cell leukocyte adhesion molecules, or the regulator of the adhesive properties of the neural cell adhesion molecule $(N-\mathrm{CAM})$ with the different content of sialic acids. But there have been no reports which confirm the existence of sialic acids in insects.

In this report, the authors found sialic acid in Drosophila melanogaster and investigated the localization and its chemical structure. At first, by the use of lectin-gold histochemical assay, with the Limax flavus lectin which is specific to sialic acids, they investigated the change in the localization of sialic acid in D. melanogaster with the embryo development. At the blastoderm stage, all cells exhibited staining, although the pole cells stained most intensively. During gastulation and in early germ band elongation, additional labeling along the central and cephalic furrows existed. After germ band shortening and during dorsal closure, intense staining was observed in all structures, although the most intense staining was in the vental nervous system and the brain ganglia. Then, the homogenate of Drosophila embryos at different development stages from fertilization to the third instars were examined to see if homopolymers of 02,8 -linked sialic acid were expressed by Western blot analysis using the monoclonal antibody MAb 735 , which recognizes PSA. PSA was detected only in 14 to 16-hour embryos, when staining in the ventral nervous system and the brain ganglia in cytochemical detection of sialic acid was exhibited, and pretreatment with endosialidase $\mathrm{N}$ and
シアル酸はノイラミン酸の誘導体の総称である。植物界を 除いて自然界に広く分布し、主として糖タンパク質、糖脂質及 びある種の細菌の莢膜多糖に結合型として存在している。天然 に存在が知られているシアル酸は、いずれも5位のアミノ基にア シル基が結合した $\mathrm{N}$-置換体であり、アセチル基が結合した $\mathrm{N}$ アセチルノイラミン酸とグリコリル基が結合した $\mathrm{N}$-グリコリル ノイラミン酸が代表的なものである。結合様式の違いにより、 シアル酸は自然界において様々な存在様式をとっており、オリ ゴ糖鎖の非還元末端や側鎖として、あるいはシアル酸同士が重 合してオリゴまたはポリシアル酸基として存在している。シア ル酸はそのカルボキシル基により負電荷を帯びていることか ら、シアル酸をもつ分子同士が反発することにより細胞表面や 生体高分子の認識部位や抗原決定部位を遮蔽する効果があるこ とが知られている一方、特定の臓器あるいは分子を認識する部 位として不可欠な例も多く見出されている。インフルエンザ ウィルスが特定のシアル酸残基に結合することにより感染を起 こす例や血清糖タンパク質の生体内での寿命がシアル酸残基の 有無により左右される例はよく知られている。最近はガン特異 性抗原としての存在や内皮細胞白血球接着分子に対するリガン ドとしての存在、あるいは神経細胞接着分子(N-CAM)上でのシ アル酸の発現量の違いがその接着性に及ほす影響等に注目が寄 せられている。しかし、シアル酸の昆虫類における存在はこれ まで報告されていなかった。

著者らは、ショウジョウバエ(Drosophila melanogaster)にシ アル酸の存在を見い出し、その局在及び化学構造について検討 を行っている。まず、シアル酸に特異的な Limax flavus レクチ ンを用いたレクチンー金コロイド染色法による組織化学的手法 により成長にともなう胚のシアル酸の存在分布の変化を調べて いる。その結果、胞胚初期には極細胞に強い染色が認められる ほかは全細胞にシアル酸が一様に存在していたものが、原腸形 成が進行するにしたがって腹部や頭部のくびれにも強い染色が 認められるようになり、肧帯が収縮して背面が閉胞する時期に は全ての構造中にシアル酸が存在するが、神経組織中に特に強 い染色がみられることがわかっだ。次に、受精直後から第3齢幼 虫に至るまでの時期の高分子画分のウェスタンブロッティング を行い、 02,8 -結合したポリシアル酸に対して特異的に反応する モノクローナル抗体(MAb 735)を用いて免疫染色法を行ってい る。その結果、背面が閉包して胚が成熟する時期、すなわち先 にシアル酸が神経節に強く局在していることが示された時期に 
preabsorption of MAb 735 with colominic acid abolished the immunostaining. The chemical structure of sialic acids both in early development and during dorsal closure was confirmed as $\mathrm{N}$-acetylneuraminic acid by a combination of gas-liquid chromatography-mass spectroscopy.

This is the first report to confirm the existense of sialic acid in insects and the universality of sialic acid in nature has been extended. It is very interesting that the temporal expression of PSA in the embryo developmental stage and abolishment of the residue after the stage were observed. This evidence suggests that PSA functions as the regulator of the embryo development. The authors estimate that PSA expressed in Drosophila embryos is on the $N$-CAM. It was reported that the PSA residue expressed on the $N$-CAM regulates the interaction between cell and cell or cell and substrate in cells derived from rat[A. Acheson, et al. (1991) J. Cell. Biol. 114, 143]. On the other hand, the difference in amount of sialic acids expressed on the $N$-CAM of embryo and adult was reported in cells derived from chickens [J.B.Rothbard, et al. (1982) J. Biol. Chem. 257,11064]. In this paper the possibility that PSA expressed on the $N$-CAM in insect brain functions similarly in other animal species and a high degree of phylogenetic conservation of $N$-CAM which has PSA were suggested. The rapid identification and investigation of the function of the molecules expressing PSA and sialic acid in Drosophila are expected.

\section{Reported by Akiko Kanamori}

Faculty of Science, University of Tokyo,

Tokyo 113, Japan
のみポリシアリル基が特異的に発現されることが、エンドシア リダーゼ処理やコロミン酸による阻害の有無によるMAb735の 反応性の違いから明らかにされた。さらに発生初期及び背面閉 包期の両時期において存在するシアル酸の分子種は両者とも $\mathrm{N}$ アセチルノイラミン酸であることがガスクロマトグラフィー/質 量分析法により確認された。

昆虫類におけるシアル酸の存在を確認した例はこの報告が 初めてであり、シアル酸の自然界における普遍性がひとまわり 広げられた。特に、胚の成長過程における一時期にのみポリシ アリル基が発現され、再び消失するという点がポリシアリル基 が肧の成長を調節する分子として機能していることを推察さ せ、興味深い。著者らはこのポリシアリル基が N-CAM 上に発 現されているものと考えている。N-CAM のポリシアリル基が 細胞-細胞間及び細胞-基質間の相互作用を制御していることが ラットの系で報告されている[A. Acheson, et al. (1991) J. Cell. Biol. 114, 143]。また、N-CAM のシアル酸の発現量が胚と成体 では異なることがニワトリの系で報告されている[J.B. Rothbard, et al.( 1982) J. Biol. Chem. 257, 11064]。今回の報告で昆虫の場合 にも N-CAM 上にポリシアリル基が発現され、そのポリシアリ ル基が他の動物種の場合と同様に機能している可能性が示さ れ、ポリシアリル基を 持つ N-CAM の系統発生上の保存が示唆 された。ショウジョウバエに存在するポリシアリル基及びシア ル酸を含有する分子の同定及びその機能の解明が待たれるとこ ろである。

東京大学・理学部・生物化学

金森 審子

\section{FCCA Is Supported by Your Membership Fee!}

Please do not forget that FCCA is supported

by your membership fee. If you have not already paid your annual membership fee of 1992, please pay it now.

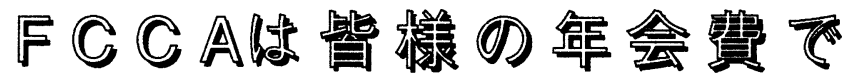

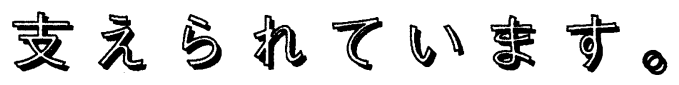

FCCAの活動は皆様の年会費で支えられ ている事をどうぞお忘れのないようにお願い 申し上げます。もし1992年度の会費が未納で したら、今すぐにお支払い下さい。 